\title{
Cytogenetic studies: an essential part of the paediatric necropsy
}

\author{
GRANT R SUTHERLAND, RODNEY F CARTER
}

From the Department of Histopathology, Adelaide Children's Hospital, North Adelaide, SA 5006 Australia

SUMMARY Chromosome studies were attempted on $97 \%$ of necropsies carried out in the Department of Histopathology of the Adelaide Children's Hospital over the four-year period ending May 1981. Results were obtained from $89 \%$ of necropsies of which $7.5 \%$ had major chromosome abnormalities. The chromosome results are analysed according to the category of the necropsy and to primary cause of death. It is recommended that cytogenetic studies be performed on all stillbirths and infants dying at less than 28 days of age except in cases of isolated CNS malformation, sudden infant death syndrome (SIDS), trauma, or known single gene defects.

Chromosome studies carried out on several series of paediatric necropsies up to 1977 were summarised by Sutherland et al $^{1}$ and the recommendation made that such studies should form part of most paediatric necropsies. The present report documents the cytogenetic findings on all necropsies at the Adelaide Children's Hospital over an additional period of four years and makes further, more detailed, recommendations concerning the application of chromosome studies at the paediatric necropsy.

\section{Material and methods}

All routine paediatric necropsies at the Adelaide Children's Hospital were studied. During the period of study the annual necropsy rate fluctuated between $75 \%$ and $80 \%$, the majority of those not coming to necropsy having died from long standing illnesses such as cystic fibrosis, thalassaemia and malignant disease. In addition some stillbirths and neonatal deaths occurring outside the Hospital were referred for necropsy and all sudden infant deaths in South Australia were examined under the authority of the Coroner. Such studies were carried out for a six-year period ending May 1981; the results of the first two years have been published, ${ }^{1}$ hence this report covers the last four years of the period.

Methods of chromosome study have been previously recorded. ${ }^{1}$ Perinatal deaths are defined as stillbirths of more than 28 weeks gestation and liveborn infants who lived for less than one week, regardless of gestation. The perinatal deaths were

Accepted for publication 25 August 1982 further subdivided into macerated stillbirths, nonmacerated stillbirths and early neonatal deaths. Older neonate refers to a baby dying between 8 and 28 days after birth, infant to a death occurring between 29 and 365 days after birth and child to a death occurring on or after the 366th day of life.

\section{Results}

The chromosome results are shown by category of necropsy in Table 1. Chromosome results were obtained for $89 \%$ of necropsies, the major area of failure being macerated stillbirths where results were obtained from only $54 \%$ of those studied. Despite their high failure rate, macerated stillbirths are considered worthy of study since they yielded the second highest proportion of chromosome anomalies. Therapeutic abortions of course had the highest yield since in many cases these were performed as the result of a prenatal diagnosis of a chromosome abnormality.

The chromosome findings according to cause of $N$ death are shown in Table 2 for the whole series excluding the therapeutic abortions and spontaneous abortions of less than 20 wk gestation. The chromosome abnormalities found in the SIDS were a $46, X Y / 47, X Y Y$ mosaic and a $t(X ; 5)$ in a male known to have this abnormality prior to death, having been investigated for severe hypospadias.

The chromosome abnormalities detected are shown in Table 3. The majority of these are typical of those found at prenatal diagnosis (mainly autosomal trisomies) or of those dying in childhood-for example, Down's syndrome. There was one case of the very rare $45, X$ male found in a babe dying on the 
Table 1 Chromosome results according to category of necropsy

\begin{tabular}{|c|c|c|c|c|c|c|c|}
\hline \multirow[t]{2}{*}{ Category } & \multirow[t]{2}{*}{ Total } & \multirow{2}{*}{$\begin{array}{l}\text { Chromosome } \\
\text { studies } \\
\text { attempted }\end{array}$} & \multirow[t]{2}{*}{ Successful } & \multicolumn{2}{|c|}{ Normal karyotype } & \multicolumn{2}{|c|}{ Abnormal karyotype } \\
\hline & & & & Male & Female & No & $\%$ \\
\hline Therapeutic abortion & 31 & 29 & 28 & 6 & 9 & 13 & 46 \\
\hline $\begin{array}{l}\text { Spontaneous abortion } \\
\text { (less than } 20 \mathrm{wk} \text { ) }\end{array}$ & 7 & 7 & 3 & 3 & 0 & 0 & 0 \\
\hline $\begin{array}{l}\text { Spontaneous abortion } \\
\text { (more than } 20 \mathrm{wk} \text { ) }\end{array}$ & 4 & 4 & 3 & 3 & 0 & 0 & 0 \\
\hline Macerated stillbirth & 51 & 48 & 26 & 12 & 9 & 5 & 19 \\
\hline Non-macerated stillbirth & 21 & 20 & 19 & 7 & 10 & 2 & 11 \\
\hline Early neonatal death & 38 & 38 & 38 & 20 & 13 & 5 & 13 \\
\hline Later neonatal death & 25 & 25 & 24 & 15 & 9 & 0 & 0 \\
\hline Older than 28 days & 210 & 208 & 199 & 107 & 87 & 5 & $2 \cdot 5$ \\
\hline Older than $1 \mathrm{yr}$ & 151 & 143 & 141 & 84 & 52 & 5 & $3 \cdot 5$ \\
\hline Total & 538 & 522 & 481 & 257 & 189 & 35 & $7 \cdot 5$ \\
\hline
\end{tabular}

Table 2 Chromosome results according to primary cause of death (therapeutic abortions and abortions of less than 20 wk gestation excluded)

\begin{tabular}{|c|c|c|c|c|c|c|c|}
\hline \multirow[t]{2}{*}{ Cause of death } & \multirow[t]{2}{*}{ Total } & \multirow{2}{*}{$\begin{array}{l}\text { Chromosome } \\
\text { studies } \\
\text { attempted }\end{array}$} & \multirow[t]{2}{*}{ Successful } & \multicolumn{2}{|c|}{ Normal karyotype } & \multicolumn{2}{|c|}{ Abnormal karyotype } \\
\hline & & & & Male & Female & No & $\%$ \\
\hline Macerated without malformation & 41 & 37 & 18 & 7 & 9 & 2 & 11 \\
\hline Macerated with malformation & 3 & 3 & 2 & 0 & 0 & 2 & $(100)$ \\
\hline Prematurity associated disease & 3 & 3 & 3 & 2 & 1 & 0 & 0 \\
\hline Primary CNS malformations & 41 & 41 & 38 & 17 & 21 & 0 & 0 \\
\hline Severe congenital malformations & 49 & 49 & 47 & 14 & 9 & 23 & 49 \\
\hline Congenital heart malformation & 56 & 56 & 56 & 29 & 25 & 2 & $3 \cdot 6$ \\
\hline Primary anoxia & 23 & 22 & 19 & 11 & 7 & 1 & $5 \cdot 3$ \\
\hline Infection & 27 & 27 & 25 & 14 & 11 & 0 & 0 \\
\hline SIDS & 142 & 141 & 135 & 81 & 52 & 2 & $1 \cdot 5$ \\
\hline Leukaemia & 15 & 15 & 15 & 9 & 6 & 0 & 0 \\
\hline Other malignancy & 18 & 18 & 18 & 11 & 7 & 0 & 0 \\
\hline Trauma & 54 & 45 & 44 & 28 & 16 & 0 & 0 \\
\hline Mendelian disorders & 21 & 21 & 20 & 14 & 6 & 0 & 0 \\
\hline Miscellaneous & 37 & 37 & 37 & 18 & 18 & 0 & 0 \\
\hline Total & 530 & 575 & 477 & 255 & 188 & 32 & 6.7 \\
\hline
\end{tabular}

Table 3 Chromosome abnormalities detected

\begin{tabular}{|c|c|c|c|}
\hline & & Chromosome abnormality & No \\
\hline (a) & $\begin{array}{l}\text { Amongst the } \\
\text { therapeutic abortions }\end{array}$ & $\begin{array}{l}47, \mathrm{XX} \text { or } \mathrm{XY},+21 \\
46, \mathrm{XX}, \operatorname{rob}(13 ; 14) \mathrm{mat},+21 \\
\text { triploid } \\
47, \mathrm{XX},+\operatorname{mar} \\
47, \mathrm{XY},+13 \\
47, \mathrm{XX},+\operatorname{del}(22 \mathrm{q}) \\
46, \mathrm{XX}, \operatorname{del}(5 \mathrm{p})\end{array}$ & $\begin{array}{l}6 \\
1 \\
2 \\
1 \\
1 \\
1 \\
1\end{array}$ \\
\hline (b) & Amongst the others & 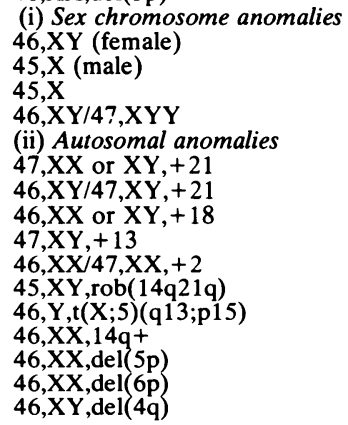 & $\begin{array}{l}1 \\
1 \\
1 \\
1 \\
5 \\
5 \\
1 \\
4 \\
1 \\
1 \\
1 \\
1 \\
1 \\
1 \\
1\end{array}$ \\
\hline
\end{tabular}

second day of life from cardiac failure due to a hypoplastic left heart. His external genitals were normal as was testicular histology. The mosaic trisomy 2 had 17/27 cells examined showing trisomy 2. This was one of macerated twins stillborn at 37 wk gestation; there was a single placenta and chromosome studies were from amnion. The main necropsy finding was of intrauterine hypoxia and there was evidence of growth disturbance at the costochondral junction. The findings in the second twin were similar except that the karyotype was normal female. The infant with del(5p) was an intrapartum death and apart from borderline microcephaly no unusual findings were made at necropsy.

\section{Discussion}

The incidence and type of chromosome abnormalities detected in this series is similar to other published series. ${ }^{1-3}$ The repeated finding of mosaic trisomy 2 is of interest since there is some doubt as to whether this is a true chromosome abnormality or an in vitro chromosome change which is particularly likely to occur when amnion is used for chromosome study. In the present series the finding of mosaic trisomy 2 in one of probably monozygous twins, with the other having a normal karyotype, suggests 
Table 4 Results of chromosome studies on unselected paediatric necropsies*

\begin{tabular}{llll}
\hline Status & No studied & No abnormal & \% abnormal \\
\hline Macerated stillbirth & 138 & 18 & 13 \\
Non-macerated stillbirth & 359 & 15 & $4 \cdot 2$ \\
Early neonatal death & 862 & 46 & $5 \cdot 3$ \\
Late neonatal death & 110 & 5 & $4 \cdot 5$ \\
Infant & 402 & 19 & $4 \cdot 7$ \\
Child & 235 & 12 & $5 \cdot 1$ \\
\hline
\end{tabular}

*Taken from references $1-3$ and the present series.

that this finding is most likely to be due to in vitro change.

In Table 4 the results of this series of paediatric necropsies have been added to those summarised previously. ${ }^{1}$ In the macerated stillbirth group the incidence of chromosome abnormality is around $13 \%$ and in all other groups it is in the region of 4-5\%. Apart from occasional sex chromosome abnormalities and balanced translocations, virtually all the chromosome abnormalities in infants and children had been recognised prior to necropsy.

The value of chromosome results, even the normal results, cannot be over-emphasised. Genetic counselling should be offered to all couples who lose a child in the perinatal period and since the question of prenatal diagnosis arises in most genetic counselling situations knowledge of the chromosome results of the dead child are particularly valuable. In the present series the finding of $\operatorname{del}(5 p)$ in a stillbirth, potentially a case of the cri du chat syndrome, was of immense help to the parents. It provided them with a reason for the death, alleviated some of their grief with the knowledge that had the child survived it would have been severely handicapped, and after they themselves had been shown to have normal karyotypes, provided positive reassurance that the recurrence risk was very small.

There are several causes of death in which chromosome abnormalities are no more common than amongst unselected liveborn children. These include deaths due to primary CNS malformation (mainly anencephaly and spina bifida), SIDS, trauma and known single gene defects. Since these diagnostic categories will usually be known by the time of the necropsy, and since there are very few unknown chromosome abnormalities detected in babies who have lived for more than one month, the following guidelines are suggested for the use of chromosome studies at the paediatric necropsy. Studies should be done on all infants dying at less than 28 days of age and on all stillbirths, except in cases of isolated CNS malformation, SIDS, trauma or known single gene defects. It is important that these exceptions are properly identified and not interpreted too loosely. For example, it is important to ensure that a CNS malformation is an isolated defect and not just one of many malformations present as occurred in one case of trisomy 18 in the present series where the most obvious feature prior to detailed examination of the neonate was spina bifida. Obviously infants older than 28 days in whom there are indications for chromosome studies should be karyotyped if this has not been done prior to necropsy.

Assistance with the tissue culture and cytogenetics was provided by Elizabeth Baker, Helen Eyre, Trudy Hocking and Erica Woollatt. Some of the necropsies were carried out by Drs GF Binns, AJ Bourne and G Phillips. Mr J Stappers' care and diligence in collecting material for chromosome analysis at necropsy greatly contributed to the success of this study.

\section{References}

' Sutherland GR, Carter RF, Bauld R, Smith II, Bain AD. Chromosome studies at the paediatric necropsy. Ann Hum Genet Lond 1978;42:173-81.

2 Machin GA. Chromosome abnormality and perinatal death Lancet 1974;i:549-51.

${ }^{3}$ Kuleshov NP. Chromosome anomalies of infants dying during the perinatal period and premature newborn. Hum Genet 1976;31: 151-60.

Requests for reprints to: Dr GR Sutherland, Cytogenetics Unit, Department of Histopathology, Adelaide Children's Hospital, North Adelaide, SA 5006, Australia. 